\title{
The Making of Odysseus the Hero in Homer's Odyssey
}

\author{
Meng Liang* \\ School of Foreign Languages, North China Electric Power University, Changping District, Beijing China
}

Corresponding Author: Meng Liang, Email: m17218@hotmail.com

\section{ARTICLE INFO}

\section{Article history}

Received: May 02, 2017

Accepted: July 28, 2017

Published: December 01, 2017

Volume: 6 Issue: 7

Special Issue on Language \& Literature Advance access: September 2017

Conflicts of interest: None

Funding: None

\begin{abstract}
This paper examines in a sociological manner how the heroic identity of Odysseus is constructed in Homer's Odyssey. The making of Odysseus the hero requires the constant testing and improving of Odysseus's heroic qualities, the existence of a largely loyal crowd to testify to his charisma, and the weaving of a myth that wraps him up. Various aspects of the Greek hero are fleshed out.
\end{abstract}

Key words: Odysseus, Hero, Crowd, Myth
Odysseus has been the central focus of Homeric scholarship. Much critical attention has been paid to such questions as the heroic qualities of Odysseus as opposed to other Greek heroes like Achilles and the typicality of Odysseus as a Greek hero. W. B. Stanford, for example, argues in "The Untypical Hero" (1983) that Odysseus, especially as represented in the Iliad, is an untypical hero who possesses some qualities that are despised by the later tradition. Discussions revolving around the heroic qualities of Odysseus, while accomplishing much in the way of bringing out different dimensions of the Greek hero, leaves the question of how the hero is constructed unanswered. My paper attempts to offer a tentative answer to this question.

People tend to be attracted by the grand facade of a hero to the extent that they are seldom concerned with the process of the hero's making, which goes on imperceptibly and constantly behind the facade. A hero is more made than born and he is always in the making, never a finished product. He must make strenuous efforts to make it possible for him to become a hero. However, his efforts alone are far from enough for making a hero. A hero is the outcome of collective efforts. This is not to say that his efforts are not important. To be a hero, he must have particular qualities that qualify him for being a hero. What qualities are those of a hero is not determined by him, but by the society he lives in. Different societies have different standards for judging if a person is a hero. Therefore, a person must meet the standard his society sets before he becomes a hero. Otherwise, whatever individual excellence he may have, he cannot possibly be a hero. The social standard, however, is not enough for making a hero either. A hero needs a crowd that supports him and is his con- trast. A hero can be a hero only when he is foregrounded by his contrast with the crowd that stays in the background and is willing to remain there forever. So far as Homer's Odyssey is concerned, mutiny poses a serious threat to the hero because it will bring the mutineer to the foreground and make him the focus of public attention. So the hero needs a loyal crowd, which will bring all its energies to bear upon the task of helping the hero accomplish spectacular feats in whatever cause the hero pursues. However, mutiny is not always a bad thing. When a mutiny turns out to be a foolish act and as a result brings a disaster even to the mutineers themselves, the hero will be able to restore his authority, which is strengthened rather than weakened by the mutiny. Order is reestablished among his crowd. Not only does the hero need a crowd, he also has to enlist the aid of a myth, a myth that establishes mysterious relations between gods and him, a myth that magnifies his charisma, a myth that meets his political need to establish and exert his authority over the crowd, a myth that the present generation and later generations hold to be true (Nagy, Greek 8). Homer's Odyssey constructs such a myth, a myth of Odysseus the hero.

In short, the making of Odysseus the hero is a complex process that requires the constant testing and improving of Odysseus's heroic qualities, the existence of a largely loyal crowd to testify to his charisma and the weaving of a myth that wraps him up.

It will be convenient to divide my study, which is conducted in a sociological manner and on the basis of textual evidence, into four stages, concerning respectively (1) Odysseus's heroic qualities, (2) hero and crowd, (3) the weaving of a myth, (4) conclusion. 


\section{ODYSSEUS'S HEROIC QUALITIES}

Odysseus has some widely acclaimed qualities that make it possible for him to become a hero. These qualities often accompany his name. When people and gods address him, they tend to bring out these qualities along with his name. That these qualities accompany his appellation points to the fact that they are universally acknowledged to be those of a hero. To be a hero, Odysseus must get the permission of the mythical society as presented by Homer, which sets the standard of a hero. But this does not mean that he cannot be individualistic. As a matter of fact, a certain degree of individualism is indispensable for a hero. The Greek hero is individualistic (McNamee 1). A charismatic hero must be extraordinary while the crowd is ordinary (Weber xviii). It is his outstanding qualities that set him apart from the crowd. These qualities become outstanding when and only when they are put to the test. They are dormant until dangers and difficulties arise. Dangers and difficulties bring these qualities into full play.

Odysseus is noted for his bravery, as is shown by Penelope's repeatedly calling him "my lion-hearted husband." Bravery does not mean that one does not have fear at all. Rather, it is the courage to overcome fear, which distinguishes a hero from the crowd whose courage has to be inspired by the hero. And his courage is all the more heroic when the danger comes from giants and monsters who are much bigger than him in stature and much more powerful than he is. When he answers the challenge the sea god Poseidon poses to him, his heroic courage reaches its peak. Thus, the more powerful his opponent is, the more heroic his bravery becomes. Or in other words, the greatest danger makes the greatest hero. The greatest danger, however, does not come from without, but from within. Fear offers no possibility of victory. The courage to overcome fear, on the contrary, empowers Odysseus to keep control of reality, however dangerous this reality is. When the pressure of this reality is too much to bear, Odysseus's patronizing god Athena or some other god will come to aid. It might be worthwhile to point out that divine help highlights Odysseus's bravery instead of detracting it. "It is an inseparable part of his greatness that he is such a locus of divine action " (Taylor 118). With or without divine help, Odysseus's bravery is extraordinary. In the long tale he tells the Phaeacians, Odysseus describes himself as an incredibly brave hero. In Book 9 entitled " In the One-Eyed Giant's Cave," he leads his crew against the giant Cyclops. The Cyclops's tremendous power is demonstrated by the act of snatching Odysseus's two crew members at once, rapping them on the ground and knocking them dead like pups (Homer 220). And his cruelty lends support to his power:" ripping them limb from limb to fix his meal/ he bolted them down like a mountain-lion, left no scrap,/ devoured entrails, flesh and bones, marrow and all!" (Homer 220). What is the reaction of Odysseus and his crew? They "wept and cried aloud,/looking on at his grisly work-paralyzed, appalled" (Homer 220). Socrates finds fault with Odysseus's tears. He holds that a hero should not shed any tears (Plato 65). Should a hero shed tears as Odysseus does on many occasions?
I would argue that tears, like divine help, do not lessen the merit attaching to Odysseus the hero who "is famous for his power to conceal his feelings" (Griffin 100) most of the time. Rather, a hero's tears strengthen his position as a hero. Tears are a sign of weakness. And weakness is human. A hero is a human being, so he has weaknesses. His weaknesses make his strengths even more conspicuous. The reason is obvious. Black is opposite to white, but when black is contrasted with white, white seems whiter than when other colors are contrasted with it or when no color is contrasted with it. The Odysseus with weaknesses is more heroic than the Odysseus without weaknesses. Tears are a sign of fear. Odysseus is a human being and a human being must have fear because he is not the most powerful. Odysseus has fear and overcomes fear, so he is a hero. Tears are a sign of sorrow. A human being has feelings and emotions. No one, even Socrates, can deny this fact. Sorrow is a natural emotion when one loses one's friends or relatives. This sorrow expressed at the loss of friends or relatives is noble because it is not aimed at oneself. It is the sign of friendship and affection, which are noble, or at least not mean. Even if it is directed at oneself, sorrow is understandable, especially when misfortune is unbearably great, as in the case of Odysseus. Odysseus is all tears when he is held back by Calypso (Homer 155). He laments his bad fortune for he cannot go back to his native land where live his wife, his son, and his father. His sorrow is personal, but this sorrow is not as personal as one might think. His affections toward his family cause this sorrow. It is rather doubtful whether he will still be all tears if he has no family members to miss at all. His sorrow merely calls attention to the other side of a hero. He is a man rather than a god, who cannot be a hero. Tears merely reveal the human essence of a hero, who is intended to be "an image of glorified human nature" (Vries 18).

Tears have three other important functions and these functions derive from the human essence of a hero. First, tears may be a widely accepted way of expressing emotions for a man. We should note the interesting phenomenon that in Homer's epic, many men shed tears for various reasons. The memory of his dead son brings tears to Aegyptius's eyes. Telemachus bursts into tears because of grief and anger (Homer 95). Odysseus and his crewmen cry every time some comrades die in the disaster. Menelaus, a king-hero, weeps for all his men and Odysseus (Homer 127). Tears spring to the eyes of Agamemnon's ghost (Homer 262). Eupithes sheds tears for his son Antinous (Homer 481). Laertes sobs for Odysseus. Odysseus's swineherd and cowherd break into tears when they see their master's bow (Homer 427) and weep again when they recognize Odysseus (Homer 431). The list could go on. Since no man seems to be ashamed of his tears, it is very likely that tears were a customary way of expressing emotions in Homer's time when poetry, as the sole way of educating people, makes people more emotional than rational. If my assertion is true, then tears are nothing to be ashamed of, even for a hero. It might even be safe to say that tears are a natural reaction for the hero of a traditional type. Actually the Greek hero is expected to cry because he is heroic (Lutz 65). His tears are "heroic tears" (Lutz's term). 
Tears do not render a hero womanly. Tearlessness has not been the standard of manliness through most of history. And the prohibition against male tears only takes center stage in the middle of the twentieth century, and even then it was not fully observed (Lutz 64). (Socrates's reaction against excessive emotions does not seem to draw enough attention to constitute a significant challenge to male tears.) Therefore tears have nothing or little to do with womanliness. Tears are neither manly nor womanly. They are merely human. By faulting Homer's traditional heroes for their tears, Socrates challenged the traditional way of experiencing things and expressing oneself. He is more concerned with establishing a new way of thinking than with the trivial question of whether a hero should shed tears. Let us save a weeping hero in time from Socrates's misplaced attack, so to speak, and probe into the social functions heroic tears serve. In lamenting the death of their comrades together, Odysseus and his crewmen observe a commonsensical code of behavior, which in turn brings them closer to each other and thus increases their solidarity. The dead must be wept for. If no one weeps for him, he is not loved by anyone. The person that doesn't deserve even one drop of tears is perhaps a demon. Hence weeping is not only an expression of inner feelings, but also a necessity of showing respect for the dead. In performing the same duty, Odysseus and his crewmen increase mutual understanding and their relations are hereby strengthened. Weeping can produce this effect in that it is ritualistic. A ritualistic act is both personal and impersonal. Socrates neglects the impersonal or rational aspect of weeping, so it comes as no surprise that he should take Homer to task.

The impersonal aspect of weeping leads to yet another function. "Impersonal" implies the power to control one's emotions. Therefore weeping is both the release of emotions and the control of emotions. This sounds contradictory, but if we take into consideration the ritualistic background of weeping we will find that actually these two aspects are in harmonious relations with each other. These two aspects are mutually conditioned. The weeping Odysseus is neither too emotional nor too rational. Ritualistic weeping improves his ability to channel his emotions in a desirable direction. A probably unexpected result follows: he is capable of controlling the emotions of his men. He can not only inspire his men's affections towards him, but also disperse or suppress their fear of dangers. His speech is commanding and sensational, authoritative and comforting. That is why his audience is often spellbound, either when he tells his long tale or when he orders his crew to fight. His speech facilitates his exercise of power over his men. No doubt bravery is displayed in action. That is why people praise Odysseus's bravery by calling him "man of exploits" or "man of action." Speech, however, is an equally important expression of bravery. In times of great danger, when his crew panic and are at a loss what to do, Odysseus's speech restores their composure and instills courage into them. His speech is part of his bravery. So far I have been trying to give credit to Odysseus's tears that Socrates discredits. Let us move from the relations between tears and bravery to all the sufferings that Odysseus has undergone.
Bravery is not the whole of what makes a hero, who has to suffer tremendously and endure tremendous sufferings. Odysseus is frequently called "the long-suffering hero" and "long-enduring great Odysseus." Long suffering and long enduring makes and tests the greatness of a hero like Odysseus. Sufferings and enduring sufferings are common fate of humanity, ordinary people or extraordinary heroes. What distinguishes an extraordinary hero from an ordinary man is either the hero's tragic death after the accomplishment of heroic feats or his triumphant emerging from his unusually long suffering. Agamemnon is the former type of hero and Odysseus the latter, if his journey to the underworld is not considered to be death in a real sense. The princess Nausicaa said to Odysseus, "He [Zeus] gave you pain, it seems. You simply have to bear it"(Homer 174). Odysseus bears his unbearable pains and in bearing pains demonstrates his outstanding survival willpower and skills.

Odysseus is also famous for his wiles. He is "man of tactics," "man of twists and turns" and "the flexible, wily king." The consideration of his tactics introduces complications into the concept of a hero. Homer describes Penelope as "the model of cautious, shrewd intelligence" (Combellack 111) who is Odysseus's double, thus tinging tactics with a feminine color. There naturally arises the quarrel between Odysseus the man of tactics and Achilles the man of might about who is the best of the Achaeans (Nagy, Best 24). This quarrel, which starts in the Iliad, is not resolved even in the Odyssey, an epic devoted to Odysseus alone. Tactics and might are opposite qualities. If tactics, rather than might, is the standard for judging a hero, Odysseus is an indisputable hero. It follows that Odysseus is the best of Achaeans. But in Book 11 "The kingdom of the Dead," Odysseus calls Achilles "greatest of the Achaeans" (Homer 265). One may argue that Odysseus just tries to appease Achilles's mournful spirit and show his respect for the dead through flattering Achilles. And there is indeed evidence of this:

But you, Achilles,

there's not a man in the world more blest than you-

there never has been, never will be one.

Time was, when you were alive, we Argives

honored you as a god, and now down here, I see, you lord it over the dead in all your power.

So grieve no more at dying, great Achilles. (Homer 265)

The word "quick" shows Odysseus's cunning and eagerness to appease Achilles. Nevertheless, Odysseus's praise of Achilles, whether this praise is sincere or not, reveals to us the possibility that an inexpedient word of his might offend Achilles's self esteem and arouse a hot dispute about cunning and might, which is still unsettled yet. Achilles is already resentful and ironical in his tone before Odysseus makes an expedient reply: "Royal son of Laertes, Odysseus, man of tactics,/reckless friend, what next?/What greater feat can that cunning head contrive?/What daring brought you down to the house of Death?/" (Homer 264-65). Odysseus's flattery avoids a possible quarrel. His flattery also serves another purpose. Odysseus is aware that he is telling a tale to a large audience including King Alcinous, another hero. In showing respect for might as a standard of hero, he implies 
that he acknowledges the merit of sailing to be another standard of hero, which King Alcinous would wholeheartedly embrace. Alcinous said to Odysseus,

So you can tell our story to other lords

as you sit and feast in your own halls someday,

your own wife and your children by your side,

remembering there our island prowess here:

What skills great Zeus has given us as well,

down all the years from our fathers' days till now.

We're hardly world-class boxers or wrestlers, I admit,

but we can race like the wind, we're champion sailors too. (Homer 199)

Alcinous's remarks indicate that there are different standards for judging a hero. Odysseus concedes this point to Alcinous by calling Achilles the greatest of Achaeans rather than of all the peoples. Therefore, Odysseus is a hero of tactics, Achilles a hero of might and Alcinous a hero of sailing. Let us return to the quarrel between Odysseus and Achilles. Just as it is impossible to know which is superior, tactics or might, so there is no way of judging who is the best of the Achaeans, Odysseus or Achilles. Dorothea Wender argues that while "Achilles is, in a sense, more divine, more brilliant" than Odysseus the resourceful human competitor, this contrast may also be in Odysseus's favor (127). It may be hard to determine who gains the upper hand as a whole, as shown by this argument, but we can surely assert that Odysseus is the best of the Achaeans in tactics whereas Achilles is the best of the Achaeans in might.

Bravery, tremendous endurance, and tactics are some of the elements that make up the charisma persona of Odysseus the hero. The charismatic persona does not come naturally to Odysseus. The establishment of this charismatic persona involves both his individual efforts and the cooperation of his men.

\section{HERO AND CROWD, LOYALTY AND MUTINY}

The making of Odysseus the hero requires the existence of a crowd, which can be either loyal or mutinous. The extra-ordinary is based on the ordinary and stands out from the ordinary; a hero lives among his crowd and emerges from his crowd. "The hero is usually a leader of men" (Bowra 105). Odysseus rules over his people. His people, however, have the freedom of choice between loyalty and mutiny. While their loyalty confirms his charisma and contributes much to the accomplishment of his heroic feats, their mutiny does not necessarily frustrate his attempt to achieve heroic status. Instead, the disaster that this mutiny brings to the mutineers and Odysseus reveals the mutineers' recklessness and Odysseus's wisdom and justice.

Homer divides Odysseus's people into two groups, one being loyal and the other mutinous. Penelope and the swineherd are representative of the loyal group. I put Penelope into the category of Odysseus's people both because being a woman she is dependent on her husband Odysseus and because Penelope is the female double of Odysseus in terms of tactics. Penelope maintains her loyalty by virtue of tactics. She neither totally rejects the suitors nor totally accepts their request. She asks the suitors to wait until she finishes the shroud for Laertes. But "by day she'd weave at her great and growing web--/by the light of torches set beside her,/she would unravel all she'd done" (Homer 96). She does so in the hope that Odysseus might come back one day and take vengeance for the reckless behavior of the suitors. The suitors catch her in the act and are angry at her deception:" So long as she persists in tormenting us,/quick to exploit the gifts Athena gave her-/a skilled hand for elegant work, a fine mind/and subtle wiles too.../Not one could equal Penelope for intrigue/but in this case she intrigued beyond all limits./So, we will devour your worldly goods and wealth" (Homer 97). Both Penelope and Odysseus exploit the gifts Athena gives them, which are a skilled hand for elegant work and a fine mind and subtle wiles. Penelope can weave a "gorgeous web"(Homer 96) and Odysseus finishes his craft "expertly" (Homer 160). No queen can equal Penelope for intrigue and no king can outshine Odysseus in tactics. Penelope's reputation is designed to enhance Odysseus's. Equally important is the swineherd's reputation for loyalty. Book 14 is entitled "The Loyal Swineherd." The Odyssey is a eulogy for Odysseus. In this epic, Homer uses a whole book to sing the praise of the loyal swineherd, a servant. The appellation "the loyal swineherd" is repeated many times. The swineherd is all the more loyal because his loyalty is witnessed by his anonymous master in disguise. In the master-servant dialogue, the servant conveys his deep affection towards his master:

Aye, leaving a broken heart

for loved ones left behind, for me most of all.

Never another master kind as he!

I'll never find one - no matter where I go, not even if I went back to mother and father,

the house where I was born and my parents reared me once.

$\mathrm{Ah}$, but much as I grieve for them, much as I long to lay my eyes in them, set foot on the old soil. it's longing for him, him that wrings my heartOdysseus, lost and gone!

That man, old friend, far away as he is...

I can scarcely bear to say his name aloud,

so deeply he loved me, cared for me, so deeply.

Worlds away as he is, I call him Master, Brother! (Homer 306)

The servant thinks that he is the most broken-hearted, even more broken-hearted than Penelope and Telemachus. This emotional hyperbole may not be true, for Penelope's heart-broken sorrow is depicted in greater detail. But the servant's emotional loyalty cannot be expressed in a better way. Why is the servant so loyal to his master? Because there is not another master that is kinder than his master. The servant is loyal to his master on account of his master's superlative kindness, another trait of Odysseus's charismatic persona. His master's kindness is even kinder than the kindness of his mother and father. This is yet another emotional hyperbole. Much as the servant grieves for his parents, it's longing for his master that wrings his heart. The master-slave tie is stronger than the blood tie. Here is the third emotional hyperbole. The servant is well aware of the class boundary between 
his master and him throughout Book 14, as is shown in his appellations "we servants," "we slaves,"”my master,"”our high and mighty masters" and "my old King." Nevertheless, he loves his master so much that he transgresses the class boundary and the spatial boundary as well. His master becomes his "old friend" and "Brother." All this because his master so deeply loves him and cares for him. Again his emotional hyperbole derives from his master's merit. The servant has a part, a significant part, in the making of Odysseus the hero because of his frequent use of emotional hyperbole. His emotional hyperboles aggrandize his master's charisma. Therefore, the ultimate purpose of devoting a whole book to the loyal swineherd is to eulogize Odysseus's charisma from the perspective of a servant.

Odysseus's crewmen are loyal to him most of the time and mutinous occasionally. Their loyalty attests Odysseus's charisma. Men gathered in a crowd turn instinctively to the person who possesses the qualities they lack (LeBon 141). Odysseus's crewmen gather around him for lack of his charisma and because of his charisma. Under the leadership of Odysseus, they pull through many disasters on their way back home. However, they are not always obedient. Many of them lose their lives due to their reckless behavior. Their death proves Odysseus's wisdom, as in the case of "The Cattle of the Sun."

In "The Cattle of the Sun" Eurylochus instigates a mutiny that threatens to deprive Odysseus of his authority. Insofar as he has a certain degree of charisma he is capable of doing so, though he is not as much of a leader as Odysseus is. His charisma is demonstrated in his mutinous speech, which is powerful, reasonable, and persuasive. His shipmates cheer his poetic speech. The community's leadership lies with those who have outstanding poetic skills (Havelock, Preface 126). Eurylochus's poetic skills enable him to gain the support of his shipmates, who are easily swayed by powerful speeches. He is not only an eloquent speaker, but also a brave man:" And so, numbering off my band of men-at-arms/into two platoons, I assigned them each a leader:/I took one and lord Eurylochus the other./We quickly shook lots in a bronze helmet-/the lot of brave Eurylochus leapt out first" (Homer 236). And he is perceptive as well: "She [Circe] opened her gleaming doors at once and stepped forth,/inviting them all in, and in they went, all innocence./Only Eurylochus stayed behind-he sensed a trap..."(Homer 237). His poetic speech, his bravery and his perception embolden him to challenge Odysseus's authority. He is a strong opponent of Odysseus. In "The Bewitching Queen of Aeaea," when Odysseus's crewmen jump to do his bidding, Eurylochus tries to hold them back and accuses Odysseus of being hotheaded (Homer 244). Odysseus quells his mutiny by threatening to use force. His men, including Eurylochus, carry out his plan and no harm comes to them. In "The Cattle of the Sun," however, Eurylochus succeeds in instigating a mutiny, which rouses anger in Zeus and results in his own death and the death of all the other shipmates. Odysseus survives this disaster, which buttresses his authority.

The suitors' mutiny and destruction make it evident that Odysseus represents justice and is the executor of justice. This mutiny may not seem to be aimed at Odysseus himself, who is supposed to be dead or unlikely to return, but its ulterior purpose is to usurp Odysseus's or his son's power over his kingdom. A hero must have a kingdom that symbolizes his heroic feats. If he is dead, his son should take his place and rule over his kingdom with a view to extending his glory to later generations. A hero deserves glory, which, like his kingdom, is another symbol of his heroic exploits. Thus, the suitors' mutiny threatens to take away glory from Odysseus and by so doing it disqualifies him from being a true hero. Therefore, Odysseus has no choice but to quell this mutiny. And he quashes this mutiny under the pretext of executing justice. In suppressing this mutiny he adds another quality to Odysseus the hero and that is, justice. Please note that justice here is not a general principle, but "what one has a 'right' to expect of human behavior in given cases from given types of people" (Havelock, Greek 191). In other words, Odysseus's sense of justice is pragmatic rather than transcendental. $\mathrm{He}$ is a hero of practical intelligence, as Jeffrey Barnouw attempts to show in his Odysseus, Hero of Practical Intelligence: Deliberation and Signs in Homer's Odyssey. We also need to know that a hero can only be a hero when he performs his public duty in practical life due to the fact that a hero is a social role. In the case of Odysseus, the pretext of executing justice transforms a personal revenge into a public duty, which reinforces his reputation for being a hero.

Whether it is loyal or mutinous, a crowd plays a decisive role in making a hero. However, this should not be taken as saying that a hero does not have to make any individual efforts. Odysseus is a man of tactics. He often calls his crewmen "brothers-in-arms" and "comrades-in-arms," which entrance them into forgetting their class difference from their king temporarily. In this way Odysseus increases solidarity and hereby enhances his own charisma. He is also a man of action. His successful attempt to quell a mutiny restores his power over his people. His individual efforts and the existence of a crowd are not sufficient for making a hero. Myth has to be introduced into this process.

\section{WEAVING A MYTH}

"Epic is not history" (Clark 38). Homer transforms history and this transformation is founded upon hero worship (Nagy, Best 10). Hero worship gives rise to myth. Homer weaves the myth of Odysseus the hero. His epic confers glory (Nagy, Best 16) because it is mingled with myth, which is designed to glorify a hero. If you perform heroic deeds, you have a chance of getting into Achaean epic and so enjoying glory (Nagy, Best 17). Homer's epic confers incomparable glory on Odysseus, who earns his way into it, through establishing his close relationship with gods. "When a god associates with a man, he elevates him, and makes him free, strong, courageous, certain of himself. Throughout his poems, Homer has his gods appear in such a manner that they do not force man down into the dust; on the contrary, whenever a great, a decisive deed is to be accomplished the god steps in and gives his advice (Snell 32). More importantly, those closest to the god in the Odyssey are not the poor and the meek, but the strong and the powerful (Snell 33). In this epic, Athena seems to accompany Odysseus, her human counterpart, wherever he 
goes. A hero is supposed to have both secular power and divine power. Odysseus already possesses secular power. Athena's aid endows him with divine power, which renders his secular power all the more impressive. His secular power is mythologized as if it originated from a god, as indicated in the phrase "our god-appointed kings"(Homer 146). Homer's gods make a hero what he is.

The material representations of a hero's glory are his wealth and palace. The loyal swineherd takes pride in his master's wealth: "Believe me, my master's wealth was vast!/ No other princes on earth could match his riches, /not on the loamy mainland or here at home in Ithaca-/no twenty men in the world could equal his great treasures!"(Homer 304). In boasting about his master's wealth he shares the glory of his master as a hero. A hero should also have a grand palace, which is the symbol of his heroic status. Homer makes an elaborate depiction of the palace of Alcinous, another great king-hero. Odysseus has a "well-constructed palace"(Homer 357) too, but Alcinous's case best illustrates the symbolic relations between a king-hero and his palace. Odysseus possesses great wealth and a grand palace. Nevertheless, he marvels at Alcious's palace. Marvelling, in Snell's words, is Greeks' reaction to a godly presence (33). Odysseus's marveling implies that Alcinous's palace is a godly presence. And it is indeed a godly presence:" And dogs of gold and silver were stationed either side,/forged by the god of fire with all his cunning craft/to keep watch on generous King Alcinous' palace,/his immortal guard-dogs, ageless, all their days"(Homer 182). The palace as a godly presence imparts the message that its owner, King Alcinous, is a godly presence. He is a god-appointed king. The same holds true for Odysseus whose palace bears witness to his glory as a hero, a god-appointed hero.

Homer composes his epic, but most of the time it is Odysseus who recounts his own stories in Homer's epic. In this sense, Odysseus is a myth-maker insofar as we confine our discussion to the text itself. Odysseus takes over the role of a poet from Homer: "Just as the poet can be conceived as a hero, in the Odyssey the hero is represented as a poet"(Thalmann 170). Odysseus the poet makes a myth of Odysseus the hero. This myth meets Odysseus's need to strengthen his political power, which in turn preserves his image as a hero. $\mathrm{He}$ is a hero, but not an Aristotelian hero who usually dies a tragic death.

\section{ODYSSEUS: A HERO WHO SURVIVES A THOUSAND DEATHS}

Odysseus is and is not a hero. He is aware of this: "Would to god/I'd died there too and met my fate that day the Trojans,/ swarms of them, hurled at me with bronze spears,/fighting over the corpse of proud Achilles!/A hero's funeral then, my glory spread by comrades-/now what a wretched death I'm doomed to die!'”(Homer 162). He is still alive, so he is not a true hero. A true hero should die, but not all deaths are heroic. While a fighting death is heroic, a drowning death is not. A true hero fights to death like Achilles. After his death, there will be a proper funeral which, on Jan N. Bremmer's view, "functions as a rite of passage for the dead into an af- terlife" (89) and his comrades will spread "his undying glory"(Homer 143). Odysseus's idea of a hero is similar to Pallas Athena's: "If you [Telemachus] hear he's dead, no longer among the living,/then back you come to the native land you love,/raise his grave-mound, build his honors high/with the full funeral rites that he deserves"(Homer 86-87). Now let us see Telemachus's hero: "I would never have grieved so much about his death/if he'd gone down with comrades off in Troy/or died in the arms of loved ones,/once he had wound down the long coil of war./Then all united Achaea would have raise his tomb/and he'd have won his son great fame for years to come"(Homer 85). Odysseus, Athena and Telemachus reach a consensus that death, funeral, and fame are three basic elements in the idea of a hero. Death is tragic, funeral sacred (Nagy, Greek 10) and fame undying. Odysseus has only an undying fame.

However, let us modify the above idea of a hero and grant him heroic status in view of the fact that he has suffered too many misfortunes that he does not totally deserve. Tremendous suffering, which is a basic element in an Aristotelian tragedy (Nagy, Greek 15), may also make a hero. Jesus suffers for all humanity and is a great sufferer. His greatness lies in his altruistic suffering. Odysseus is also a great sufferer, though not as great as Jesus and not great in the same sense of the word. In addition to this, he is exceptionally brave and crafty. In Greece there are innumerable heroes (Kirk 145). These heroes cannot possibly fall into the same category. We should allow scope for different types of heroes. Odysseus is heroic in his own ways. However, all the heroes have one thing in common: they are always in the making and the making of them requires heroic qualities, a crowd, and a myth.

\section{REFERENCES}

Aristotle. Poetics. Trans. Richard Janko. Indianapolis: Hackett, 1987.

Barnouw, Jeffrey. Odysseus, Hero of Practical Intelligence: Deliberation and Signs in Homer's Odyssey. Lanham, MD.: UP of America, 2004.

Bowra, C.M. Heroic Poetry. London: Macmillan, 1966.

Bremmer, Jan N. The Early Greek Concept of the Soul. Princeton, N.J.: Princeton UP, 1993.

Clark, John. A History of Epic Poetry. New York: Haskell,1964.

Combellack, Frederick M. "Wise Penelope and the Contest of the Bow." Twentieth Century Interpretations of the Odyssey. Ed. Howard W. Clarke. Englewood Cliffs, N.J.: Prentice-Hall, 1983. 103-111.

Griffin, Jasper. "Characterization." Twentieth Century Interpretations of the Odyssey. Ed. Howard W. Clarke. Englewood Cliffs, N.J.: Prentice-Hall, 1983. 92-102.

Havelock, Eric A. The Greek Concept of Justice: From its Shadow in Homer to its Substance in Plato. Cambridge: Harvard UP, 1978.

Preface to Plato. Cambridge: Harvard UP, 1982.

Homer. The Odyssey. Trans. Robert Fagles. New York: Penguin, 1997.

Kirk, G.S. The Nature of Greek Myths. Woodstock, 
New York: The Overlook Press, 1975.

LeBon, Gustave. The Crowd. New Brunswick: Transaction, 1995.

Lutz, Tom. Crying: The Natural and Cultural History of Tears. New York: Norton,1999.

McNamee, Maurice B. Honor and the Epic Hero. New York: Holt, 1960.

Nagy, Gregory. Greek Mythology and Poetics. Ithaca: Cornell UP, 1990.

The Best of the Achaeans: Concepts of the Hero in Archaic Greek Poetry. Baltimore: Johns Hopkins UP, 1979.

Plato. The Republic. Trans. Allan Bloom. New York: Basic, 1968.

Snell, Bruno. The Discovery of the Mind in Greek Philosophy and Literature. New York: Dover, 1982.

Stanford, W. B. "The Untypical Hero." Twentieth Cen- tury Interpretations of the Odyssey. Ed. Howard W. Clarke. Englewood Cliffs, N.J.: Prentice-Hall, 1983. 52-71.

Taylor, Charles. Sources of the Self: The Making of the Modern Identity. Cambridge: Harvard UP, 1989.

Thalmann, William G. Conventions of Form and Thought in Early Greek Epic Poetry. Baltimore: Johns Hopkins UP, 1984.

Vries, de Jan. Heroic Song and Heroic Legend. London: Oxford UP, 1963.

Weber, Max. Introduction. On Charisma and Institution Building. Chicago: U of Chicago P, 1968.

Wender, Dorothea. "In Hades' Halls." Twentieth Century Interpretations of the Odyssey. Ed. Howard W. Clarke. Englewood Cliffs, N.J.: Prentice-Hall, 1983. 112-129. 